\title{
Privatising public space in post-apartheid South African cities through neighbourhood enclosures
}

\author{
Karina Landman \\ CSIR Building and Construction Technology South Africa, Building 2, PO Box 395, Pretoria 0001, \\ South Africa (Tel.: +27 12841 2084; e-mail: klandman@csir.co.za)
}

Key words: enclosed neighbourhoods, gated communities, post-apartheid South African cities, privatising public space, spatial fragmentation.

\begin{abstract}
In the past five years the numbers of enclosed neighbourhoods have significantly increased in South Africa. These are existing neighbourhoods that are closed off through gates and booms across the roads. Many of these neighbourhoods are fenced or walled off as well, with a limited number of controlled entrances/exits, manned by security guards in some cases. The roads within these neighbourhoods were previously, or still are public property and in most cases the local council is still responsible for public services to the community within the enclosed neighbourhoods. In this way public urban space is privatised, whether formally or informally. I will explore the distribution of enclosed neighbourhoods in South Africa on a national scale and within two metropolitan municipalities, viz., the Cities of Johannesburg and Tshwane. Then I proceed to highlight the nature and impact of these neighbourhoods on the privatisation of public space and draw on a wide basis of empirical data obtained through a national survey and in-depth case studies. Finally I will conclude with examples of lessons learnt from South Africa and how these may relate to international experience and future research on gated communities.
\end{abstract}

\section{Introduction}

In many neighbourhoods in South African cities, especially in the larger metropolitan areas such as Johannesburg and Pretoria, residents have responded to crime through road closures and access control. These residents believe that life within an enclosed neighbourhood, as they are called, provide a solution to crime and an improved quality of life. Emerging research, however, raises serious concerns regarding the socio-spatial impact of enclosed neighbourhoods in South Africa. Yet, several municipalities continue receiving proposals and requests from groups of residents to close of their neighbourhoods and local roads to control access into these neighbourhoods. Some groups even enclose neighbourhoods without formal permission. Meanwhile confronted citizens respond in the form of major public outcries.

This paper is structured in three main parts, focussing on South Africa's past; its present and speculating on the future. While the focus is on gated communities, and more specifically enclosed neighbourhoods, I argue that one cannot consider the present day manifestation and its meaning without understanding the past and its possible interpretation regarding the future. I begin by unravelling the physical and symbolic value of spatial intervention and transformation through enclosed neighbourhoods in post-apartheid South Africa. I draw on a wide variety of empirical data obtained through a national survey and on four case studies ${ }^{i}$. 
In South Africa, despite many attempts at reconstruction, cities still reflect the footprints of the past in the spatial leftovers of apartheid, which serve as a constant reminder of inequity and segregation. In addition, new types of developments such as gated communities recall memories of the past. A number of questions remain unanswered, such as who really 'owns' or controls the roads inside the closed off areas? Is it the local council or the residents inside the enclosed neighbourhoods? And how should it be interpreted: legally or symbolically? While many people simply ignore questions expressed regarding the meaning of gated communities in South Africa, it is essential to address these if the country is considering its future. The time has come to investigate the message expressed through the nature and growth of these types of developments. The question is whether they are signs of an inevitable future, a new apartheid city.

\section{Gated fences: do they really matter?}

The city... does not tell its past, but contains it like the lines of a hand, written in the corners of the streets, the gratings of the windows, the banisters of the steps, the antennae of the lighting rods, the poles of the flags, every segment marked in turn with scratches, indentations, scroll (Calvino, cited in Short 1996, p. 390).

This paper uses the manifestation of gated communities in post-apartheid South Africa to investigate three broader issues, viz., that the built environment embodies meaning, that meaning is influenced by context (socio-spatial) and that both meaning and context are affected by time.

The form of the city (the built environment) embodies meaning and relates something of the wider society. According to Rapoport (1990) there are three levels of meaning: the high level meaning relating to cosmologies and worldviews; the middle level meaning reflecting status and wealth; and the low level meaning relating to the everyday use of space. Any building, group of buildings or other significant physical intervention, will condense the different levels of meaning. The meaning of the built environment is, however, not fixed or constant. The meaning of particular parts of the built environment is not anchored permanently but floats in a sea of competing ideas, differing values, and antagonistic political and economic forces (Short, 1996, p. 394).

Urban form thus provides the setting for human behaviour and social interaction, which in turn provides the basis for meaning. For example, Tiananmen Square in Beijing was constructed as a symbol for socialist China. However, due to the mass killings in 1989, the square became associated with brutal repression and an out-of-touch, aging, political leadership. In this way, the square, built to commemorate Chinese communism, had become a symbol of its tarnished reputation (Kostof, 1992; Short, 1996). As such, meaning can also change over time through behaviour or the specific use of space or as related to specific historical realities. The interpretation of spatial transformation should therefore acknowledge this: "People have often said 'the city' when they meant capitalism or bureaucracy or centralised power... We need to put these ideas to the historical realities; at times to be confirmed, at times to be denied" (Williams cited in Short, 1996, p. 350).

Meaning is not only conveyed through urban form (physical space), but also through images or perceptions of space, place or physical interventions. Short (1996) maintains that the city is more than a physical entity, more than just a place where people live and work. The city is a place symbolic of many things, representing a variety of things. Therefore the city is a work of imagination in a sense, a metaphor, and/or a symbol, where physical space/place can be considered through perspectives or myths that are totally a product of social construction, for example, the pro-and-anti-urban myths. Each of these myths can create their own images and interpretations of city life. As such, meaning can be physical or symbolic. In this way urban form can also be considered as a form of 'text', embodying meaning (Ellin, 1997). 
This paper investigates the meaning of enclosed neighbourhoods in post-apartheid South Africa by focussing on their implications for the nature and use of public space. Public space is important because it "expresses and also conditions our public life, civic culture, everyday discourse" (Walzer cited in Madanipour, 1996, p. 146). As such, Tibbals points out that the public realm is therefore "the most important part of our towns and cities. It is where the greatest amount of human contact and interaction takes place" (cited in Madanipour, 1996, p. 146). Tensions emerge when a focus on individual places leads to the transformation of public spaces for all to 'common' spaces for only a selected few.

This is especially the case in post-apartheid South Africa where the freedom of access to public space is often emotionally loaded. It carries with it a memory of the past and an indication of a possible future. It is, therefore, not a surprise that any contemporary interventions in the built environment will also be judged against the past. As such, one cannot understand the present or the future without understanding its past. Consequently, Terreblanche (2002) maintains that it is important in South Africa to remember the past and in such a way to understand the future.

\section{The past: distances of despair}

Black workers were also part of urban communities and so the struggle over time in the workplace came to be closely tied to the struggle over the nature and control of urban space (Swilling, 1991, p. x).

South Africa has a history of racial segregation, which started during the time of colonialism (Terreblance, 2002). This was institutionalised during the apartheid era (1948-1994) and resulted in a struggle for the control of urban space. Consequently planners started to rearrange society into racial categories (Swilling, 1991). In essence, apartheid provided an ideology of segregation that was legally enforceable ${ }^{\mathrm{ii}}$. Through spatial separation, influx control, and a policy of 'own management for own areas', apartheid aimed to limit the extent to which affluent white municipalities would bear the financial burden of servicing disadvantaged black, coloured and Indian areas (White Paper on Local Government, 1998). For such a system to function properly, it required a very complex and deliberate approach to local urban planning and management.

Planners in South Africa very effectively made use of modern town planning ideas to assist with the creation of the apartheid city (Dewar et al., 1990; Dewar and Uytenbogaardt, 1991; Mabin, 1992; Kotze, 1999). In this process, protagonists of the apartheid city saw an ideal opportunity to implement their own ideology. Numerous model neighbourhoods were laid out according to race groups. Well developed, traditionally white, suburban areas developed around the central business districts where the majority of the facilities and job opportunities were located, while numerous townships grew on the peripheries of cities. Later, many informal settlements also developed in and around the townships. These areas were separated from the well developed suburbs through buffer strips in the form of green belts, industrial zones and rapid transport routes ${ }^{\text {iii }}$. A pattern of segregation through distance was created.

The results of these policies were staggering, leaving South Africa with cities that promoted inequity, were difficult to manage well and functioned poorly (Swilling, Humphries and Shubane, 1991; Tomlinson, 1994). While it offered a good quality of life to those who were allowed to live in well developed suburbs close to the inner city (whites), others were forced to live in poorly developed townships on the urban periphery on even further away in the homelands. Blacks were only allowed in the city as temporary migrant workers and very little was done to improve the living conditions in the 
African townships. Their peripheral location also meant long travelling distances and extended working days (Figure 1). In addition, apartheid left distinctive spatial characteristics ${ }^{\text {iv }}$. Cities were characterised by spatial fragmentation, segregation and low-density sprawl (Dewar, 1992).

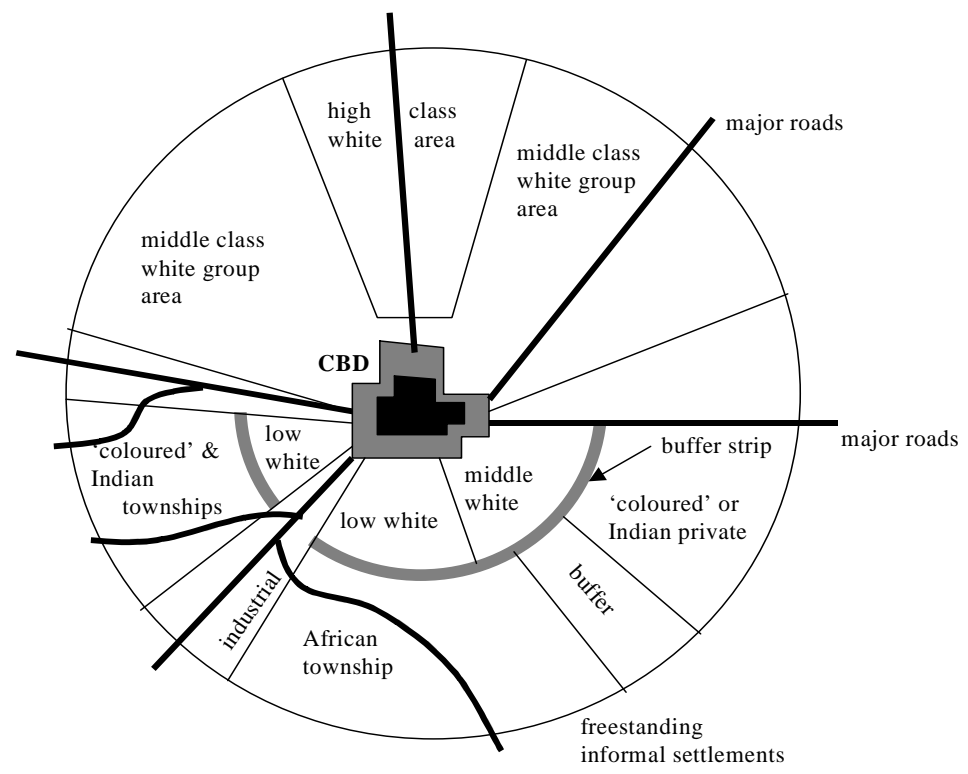

Figure 1. The "Apartheid City" (after Davies as adapted by Napier et al., 1999).

Although the infamous Group Areas Act was abolished in 1990 and many political parties were no longer banned, the actual transition to democracy occurred with the first all-inclusive elections held in 1994. Since then, South Africa has experienced profound changes including political, social and spatial transformations.

\section{The present: railings of restriction}

The post-apartheid city provides a space

... where new visions of the city collide with the old; where leaders of the poor and dispossessed negotiate politely with the advocates of the wealthy and privileged; . . . But the history itself still has a part to play in the present. For we cannot easily escape from the entrapment of the already fixed concrete form of the city (Robinson, 1996, p. 7).

The 1990s brought about significant reconstruction and development. The overall aim of the new planning and development policies was towards greater integration and sustainability. The process of transition culminated in the development of the White Paper on Spatial Planning and Land Use Management (2001), which promoted the principles of sustainability, equality, efficiency, integration and good governance.

The main impact of the 1990s, with respect to narrowing inequalities, has been the improvement of service infrastructure in poor parts of South African cities, most notably former black and coloured townships. Otherwise, the apartheid legacy has been carried into the post-apartheid era largely intact. The major structural reforms required to alter the trajectory of urban change initiated in the 1980s did not take place. Thus social justice remains a major challenge in South Africa's increasingly fragmented cities, especially for those subscribing to egalitarian ethics (liberal or social), which underpins much of the opposition to apartheid (Smith, 2003, pp. 30-31). 
Despite many efforts to address the past, the spatial patterns are to a large extent still visible and in place today. In addition, the old patterns are reinforced by new patterns of segregation (partly in response to high levels of crime), such as gated communities (Bremner, 1999; Lipmann and Harrris, 1999; Vrodljak, 2002; Harrison, 2003).

\section{Definitions of gated communities in South Africa}

Gated communities refer to a physical area that is fenced or walled off from its surroundings, either prohibiting or controlling access to these areas by means of gates or booms. In many cases the concept can refer to a residential area with restricted access so that normal public spaces are privatised or use is restricted. It does not refer only to residential areas, but may also include controlled access villages for work (office parks) and/or recreational purposes. Gated communities in South Africa can broadly be categorised as security villages and enclosed neighbourhoods.

"Security villages" refers to private developments where the entire area is developed by a private developer. These areas/buildings are physically walled or fenced off and usually have a security gate or controlled access point, with or without a security guard. The roads within these developments are private and, in most cases, the management and maintenance is carried out by a private management body. Security villages not only include residential areas (such as townhouse complexes and high-rise apartment blocks), but also controlled-access villages for business purposes (office blocks) and mixeduse developments, such as large security estates.

"Enclosed neighbourhoods" refer to existing neighbourhoods that have controlled access through gates or booms across existing roads. Many are fenced or walled off as well with a limited number of controlled entrances/exits, and security guards at these points in some cases. The roads within these neighbourhoods were previously, or still are, public property, depending on the model used within different local authorities. The majority in the country are based on the public approach (where the roads remain public). This paper focuses on enclosed neighbourhoods.

\section{National distribution of enclosed neighbourhoods in South Africa}

The numbers of enclosed neighbourhoods within municipalities differ substantially. The national survey $^{\mathrm{v}}$ conducted in 2002 identified the highest numbers of enclosed neighbourhoods in Gauteng, with two municipalities having from 7 to 9 neighbourhood closures, two having from 16 to 25, one from 25 to 100 and one with more than a hundred. Two of the three metropolitan municipalities in Gauteng had the highest numbers of enclosed neighbourhoods at the time of the response, viz., Tshwane with 35 and Johannesburg with roughly 300. There were also two municipalities in the Western Cape with higher numbers; these included Cape Town and Mossel Bay. The City of Cape Town metropolitan municipality recorded 25 neighbourhood closures at the time of the survey, and the Mossel Bay municipality 20 (Figure 2). There are also a number of illegal closures in many municipalities. Five municipalities were aware of illegal neighbourhood closures in their areas at the time of the response. 


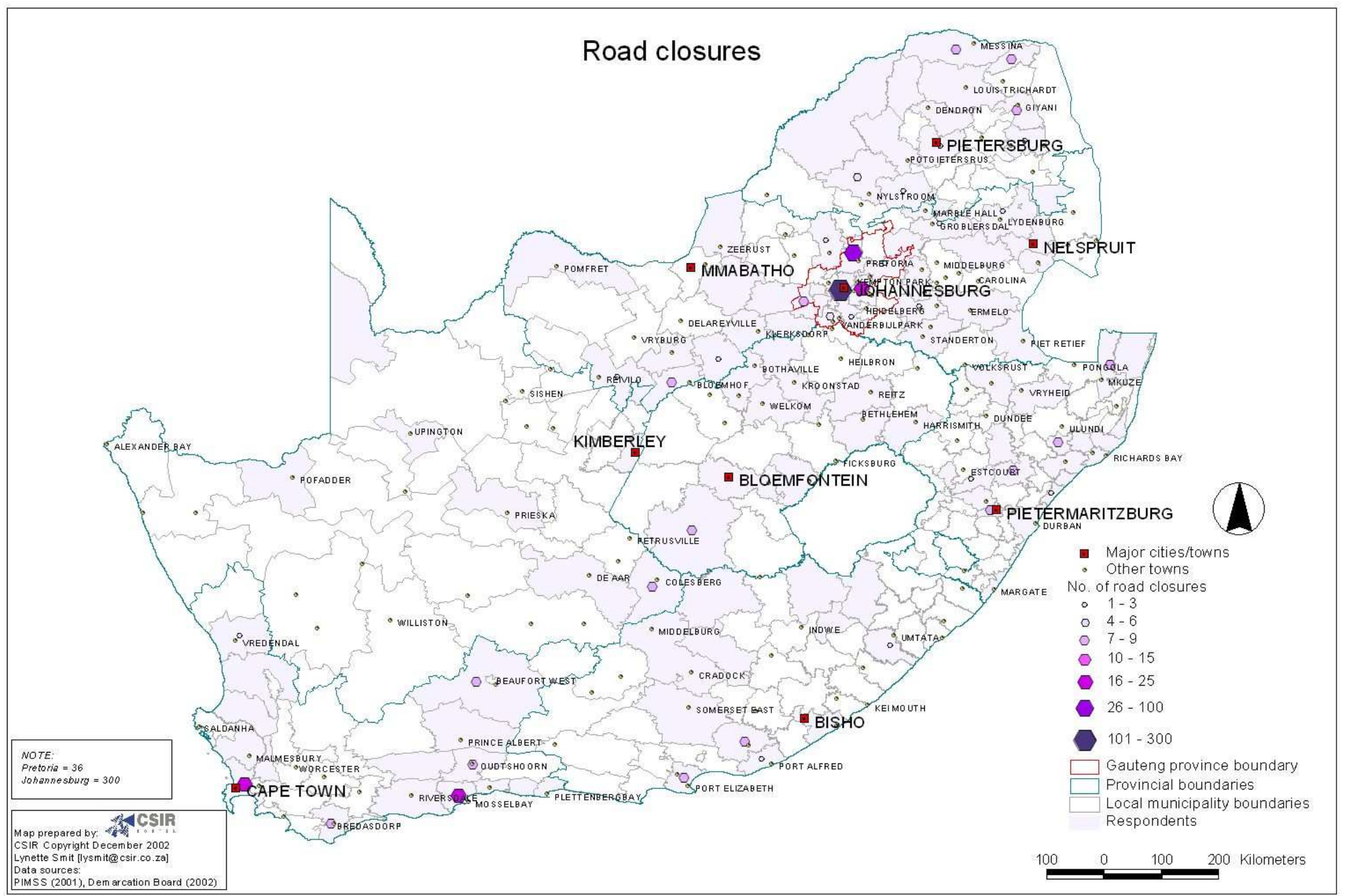

Figure 2. National

distribution of road

closures in South Africa

(Landman 2003). 


\section{The distribution in the Cities of Johannesburg and Tshwane}

The City of Johannesburg reported that there were 49 legal neighbourhood closures with a further 37 that had expired since approval. In addition, there were an estimated 188 illegal closures and 265 pending applications. The city of Tshwane had 75 formal applications from neighbourhoods to close off their areas. In addition, 35 more applications have been approved at that time. These figures demonstrate a large demand, which in turn will have a greater impact on urban development.

\section{The impact and implications of enclosed neighbourhoods for public space}

In focussing on the meaning of enclosed neighbourhoods for public space in post-apartheid South Africa I next assess their physical meaning and symbolic meanings.

\section{Physical meaning}

The physical meaning is discussed in terms of three issues: integration and accessibility, equity, and efficiency. All relate to the way in which the transformation in the physical form affects the daily use patterns of residents.

\section{Integration and accessibility}

One of the ways in which socio-spatial integration can be measured is through the degree of accessibility available to all urban residents. It refers to the ease of access to opportunities and facilities that exist within cities. One of the great benefits of cities is the economic, social, cultural and recreational opportunities and facilities which can be generated as a result of the physical agglomeration of many people. However, there is little use offering or generating opportunities if access to them is limited to a very selective number of people. In positive performing environments it is possible for poorer inhabitants to gain access to opportunities and facilities which are generated through the resources of the more wealthy as a result of integration (Dewar and Uytenbogaardt, 1991).

Providing these opportunities is one of the great benefits of a well developed system of public spaces and spaces within cities. Enclosed neighbourhoods, however, contribute to the privatisation of public space and often the opportunities and facilities contained within. It does so by restricting access into existing neighbourhoods through booms or gates across roads. These physical restrictions can be accessible (used daily) or inaccessible (permanently locked and not available for daily use). In some cases gates are operated by remote control and only accessible to residents. As a result the number of entry / exit points into or out of a neighbourhood is reduced and limited to a few, depending on the size and layout of the area.

These barriers have a major impact on urban traffic and movement patterns, especially where there is a large concentration of enclosed neighbourhoods in a sub-metropolitan area. Vehicles are displaced and forced to make use of only the main arterials (that is, the through-routes), which increases traffic congestion and travelling time. Pedestrians and cyclists also have to negotiate these busy arterials, since the lower order streets are closed. This situation does not only increase the vulnerability, but also levels of discomfort and travelling time as they often have to use much longer routes due to road closures. In this way and through the privatisation of what lawfully still remains public space ${ }^{\mathrm{vi}}$, accessibility is reduced or restricted to such an extent that it has a major impact on the daily use patterns of urban residents in, for example, Johannesburg and Tshwane. In this regard, it also contributes both to a reduced quality of life for those residents negatively affected and raises concerns about equity within South African cities. 
Contained within the concept of access are issues of equity; all urban residents should enjoy relatively easy and equitable access to urban opportunities. Positive and well-performing cities are equitable. This condition does not imply that they are ubiquitously uniform, rather, through their structure and form (topology and morphology), they enhance and promote urban activities. In this way these cities allow all people easy access to the opportunities they generate (Dewar and Uytenbogaardt, 1991).

By restricting (and prohibiting) access to large parts of urban areas, neighbourhood closures reduce and negate many urban activities and constrain many aspects of urban life for a number of people. Many opportunities previously generated are lost due to the privatisation (in practice) of former public spaces and amenities. Apart from personal losses; they also often contribute to larger scale inefficiencies.

\section{Efficiency}

This concept refers to the effective performance of cities, especially with regards to their functioning and management. In other words, certain actions (spatial intervention and land use controls) can enhance or reduce the degree of efficiency. While some enclosed neighbourhoods may not present a great problem when considered in isolation, the problem escalates when considering these neighbourhoods in a larger context. Therefore, while a single enclosure may not have a significant impact on issues such as traffic and other movement patterns, several enclosures may indeed have, because of the ripple effect as well as the fact that many are not suited to road closures because of their physical layout and position within the entire network system. This situation is evident when one considers one of the case study areas in Johannesburg in a larger context. It is located in a broad area that comprises many neighbourhood closures. By closing off a large number of neighbourhoods, the existing urban form and road network are severely affected and transformed (Figure 3). Large areas are now changed into isolated and inaccessible super-blocks, with little resemblance to the original fine-grained urban form (Figure 4). Through traffic is also limited to a few major arterials which often leads to increased congestion and longer travel times.

In addition, many road closures also cause problems for the functioning of emergency services. Due to the closure of certain roads, there is not sufficient turning space for large cleaning and maintenance vehicles. Some local authorities also expressed concern about the damage to service vehicles, problems with waste removal and the reading of water and electricity meters. The rapid response times of police and other emergency services (fire-trucks, ambulances, etc.) are also compromised by a large number of road closures. For instance, in many cases the shortest route to a specific point in need of attention is closed which forces emergency vehicles to take a more circuitous route. Also residents sometimes close routes (illegally)

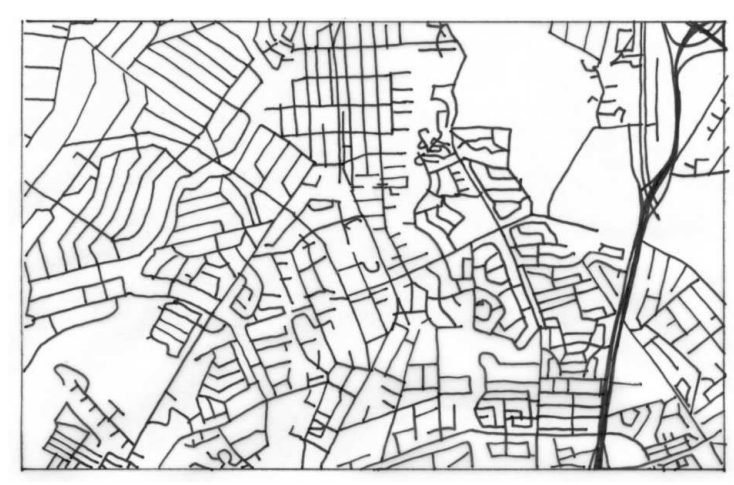

Figure 3. Original street layout

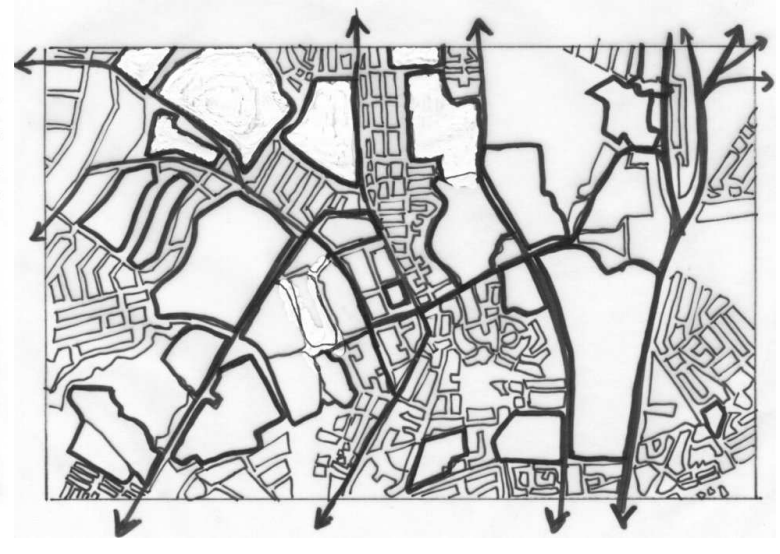

Figure 4. New urban form after the establishment of a large number of enclosed neighbourhoods without informing the police, emergency services and local councils, which causes them to end up in dead ends. Both these aspects have major implications 
for response times in cases of emergency, and could mean the difference between life and death. They also reduces the efficiency with which many daily activities and services can be performed.

\section{Symbolic meaning}

This concept relates to people's interpretation ('reading') of specific spatial interventions, in this case, gates, fences and access control. It starts to address the more subtle and psychological implications of the establishment of neighbourhood closures. The symbolic meaning is discussed in terms of three main aspects: seclusion, exclusion and conflict.

\section{Seclusion}

This refers to "a state of being private and away from other people" or "a sheltered or private place" (The Concise Oxford Dictionary, 1999, p. 1293). Enclosed neighbourhoods do exactly what the name implies, they create a physical enclosure. It is interesting that the dictionary definition maintains that enclosure is "the process or policy of enclosing wasteland or common land so as to make it private property, as carried out in Britain in the $18^{\text {th }}$ century and early $19^{\text {th }}$ century" (The Concise Oxford Dictionary, 1999, p. 469). This definition raises two issues, viz., the relationship between physical and social space as well as the direct connection between physical action and meaning.

The process of enclosure is aimed at privatising space through physical closure, thus transferring the area from public to private ownership and/or use. Accompanying this physical closure comes a growing feeling of achievement, status and prestige. The notion of 'privatisation', however, creates a dilemma: while this is exactly what happens in practice and how many patrons view and apply the concept. Legally roads and other 'public' spaces inside the neighbourhoods remain public property, yet access is controlled or restricted and prohibited. Therefore, whether intended or not, enclosure creates the notion of seclusion or in other words a neighbourhood "away from other people". This situation becomes an issue of "us" and "them", or "insiders" and "outsiders" (other people), which in turn creates fertile ground for stereotyping and exclusion.

\section{Exclusion}

This notion refers to "the process or state of excluding or being excluded" (The Concise Oxford Dictionary, 1999, p. 496). It also raises questions around who are being excluded. Again it is in examining the definition of the verb where it assumes special meaning. "Exclosure" refers to "an area that is sealed off by a barrier" and/or "an area from which unwanted criminals are excluded". The first definition highlights the physical nature of an exclosure (defined through barriers) and the second alludes to the purpose, viz., a place to exclude criminals. The dilemma, however, becomes one of how to identify potential criminals. This is where stereotyping plays an important role and barriers start to exclude randomly, including everyone that is not part of "us". An example from one of the case study areas (a typical neighbourhood enclosure in Johannesburg) illustrates the point. One of the people employed with security who prepared job descriptions of the security guards explained their role:

They basically know who they should keep in and who they should keep out. They know who looks suspicious, e.g. any three males in a car, any two or three males. They will actually stop at the gate and go through a questioning process. Any family situation, irrespective of colour, they will never question. Any single person especially a female they will never question, even if that person is a stranger.

Perceptions play a very important role in the fear of crime (Banister and Fife, 2001). They often lead to gross generalisation and stereotyping, as in the above case. It is not only blacks that are often 
stereotyped, but also groups of males. In another case study area (a typical neighbourhood enclosure in Tshwane), there was also an incident where a worker's family could not gain access to visit her. The family was away on holiday and the phone just rang inside the house. As a result, her children were turned away at the gate. Actions such as these start to create resentment and eventually lead to conflict.

\section{Conflict}

The research findings identified several levels of conflict related to enclosed neighbourhoods in South Africa, including conflict between residents inside, conflict between those inside and outside (including residents from surrounding neighbourhoods and the local council) and inner personal conflict.

According to the existing legislation in the Cities of Johannesburg and Tshwane, at least $80 \%$ of all the residents staying within a neighbourhood have to be in favour of the closure before an application can be submitted and considered. This figure means that up to $20 \%$ can oppose the application. While there is room for formal objections, these often do not carry enough weight and in many cases neighbourhoods are granted approval, which has given rise to conflict between those in favour and those against. One of the ways in which those against are "punished" is through denial of an access disc. Residents staying inside neighbourhood closures are provided with a disc to ensure fast entry (often there is a separate entrance for this purpose). Those "against" are refused a disc and have to follow the normal procedure applicable to visitors. In most cases, visitors are stopped and asked regarding the purpose of the visit and they often have to complete a register requesting information of a personal nature. The alternative is that frequent visitors (including employees) need to have ID cards to gain access. An extract from one of the case study areas reflect the views of an inside resident:

My direct neighbour is one of those who decided she did not want to be part . . but now she leaves her gate open. Those who are not in must also have an ID card like the black domestic workers. . . They don't sign in or anything else. But one feels that they should sign in and out every day if they don't want to be part of the group.

This extract clearly indicates resentment. The neighbour does not contribute financially, but receives the benefit of, allowing her to leave her gate open. She has to go through the visitor's entrance every day, although she does not have to complete the register every time. This particular resident, however, fails to consider that the person may not agree to the closure in principle and that it may in fact restrict her personal choice to a free and open neighbourhood. In another case study area, the resident did acknowledge this, but highlighted the nature of the dilemma (personal security versus security for all), reflecting this person's inner conflict:

I wanted to do this interview with you because it scares me that I am feeling so privileged and so protected, because does this mean that for everybody in SA or everybody in urban areas we all have to live in these estates? Do you understand what I am saying - what are they going to do? Are they now going to make these estates in Soweto in certain areas? Does the whole Johannesburg have to go this way?

This response to gated communities poses warning signs. Many people object to a restriction of access to public roads which is also prohibited by the South African Constitution. The question of access often leads to resentment. Whereas the public accepts that they cannot gain access to a private development without permission, many protest against access control in enclosed neighbourhoods. It is therefore not surprising that the outcry against this type of spatial intervention has been far greater compared to those living in security villages. It is apparent that enclosed neighbourhoods are contributing to significant socio-spatial transformations in SA cities, e.g. Johannesburg and Tshwane. The question is how this will turn out in the future. While the physical meaning sheds more light on 
the more immediate implications of the spatial interventions (railings against restrictions), the symbolic meaning starts to shed light on a possible future, viz., people's interpretation of the neighbourhood gates and fences as symbols of seclusion and exclusion.

\section{The future: symbols of seclusion}

The barbed wire and other barricades that now characterise the suburbs of the super rich echo the bad old days ... (Ronge, 2003, p. 6).

Where has all the public space gone? All that is left is a city of urban forts. These forts are scattered across the urban environment, creating an intricate maze of secluded neighbourhood cells. Wealthier citizens live, work and play in these bastions of concrete and steel connected to each other by sky bridges and armoured vehicles. Juxtaposed to this fortified maze is the war zone, a den of deadly forces competing for control. This space is also the living place of the poor who have to face the dangers of unprotected areas. They are the street people of the "dead-spaces", literally and figuratively. No longer are public spaces shared by all urban residents. It is only those who are excluded from the gated city who are left to live their lives in this derelict and dangerous maize of misery.

This description depicts a possible worst case scenario of what a city such as Johannesburg could become in 20 years. Perhaps it is too exaggerated and, hopefully, it will never become reality. But the current historic realities and echoes from the past cast ominous signs, presenting a possible scenario of a new apartheid city far worse than history offered. While it may to a large extent only feature in people's perceptions (symbolic meaning of gated communities), the alterations to daily life (physical meaning) are increasingly raising concerns and even outright anger from many commentators and residents. Tomlinson (2003, p. 86), commenting on the sharp distinctions and inequalities between the wealthy and poor areas in Johannesburg, warns of the divide between "the walled residential communities and secure office parks and malls in the north [which] will stand in sharp contrast to the desperation of the south". A well know social commentator and critique takes it a bit further. He recently commented on the establishment and proliferation of enclosed neighbourhoods in Johannesburg and linked them to the creation of new apartheid neighbourhoods:

To me it sounds like history is repeating itself. We are dealing with a situation in which a certain group of people are forbidden to be in particular areas after a given time at night. They may also not walk the streets in those areas unless they have specific permission to do so. Am I the only one who hears an echo of the bad old days when the curfew and the dompas were enforced to keep black people off the streets in white neighbourhoods? The whites had a "right" to be there because it was "their" place. The blacks were forced to stay in areas designated as "their" place and could only come into white areas with specific permission to work as servants. How does that historical situation, so despised and opposed in the past, differ from the condition that is spreading through the exclusive suburbs of Johannesburg? The only real difference is that it is no longer race based (Ronge, 2003, p. 6).

The creation of neighbourhood closures is inevitably linked to the past as the legacy of the past returns to haunt the future. The current interventions are interpreted through an historical lens. Gated communities have been labelled as "racist", compared to "apartheid influx control" and hailed as "new laagers of apartheid". Neighbourhood enclosures have been the subject of many heated debates and newspaper/magazine articles. Through their very nature, they are and could even further create another barrier to integration and interaction and may add to the problem of building social networks that provide opportunity for social and economic activities. A few writers have suggested that they may actually contribute to the establishment of a new apartheid city in South Africa (see Beavon, cited in 
Jürgens, U., Gnad, M. and Bhar, J., 2003 and Spinks, 2001), both physically and symbolically. In her study on urban spatiality, crime and segregation in Cape Town, Spinks (2001) found that citizen residential strategies have undermined government planning and increased the amount socio-spatial segregation in post-apartheid Cape Town. She maintains that this "New Apartheid" is not driven by the fear of crime, but fear of (and prejudice against) the 'other', and encouraged by South Africa's exclusionary history.

Redressing this urban socio-spatial inequality (to facilitate development), requires challenging exclusionary mind-sets (i.e. symbolic rather than physical space [underlined in original text] (Spinks, 2001, p. 30).

In this way she emphasises the meaning of physical space. Urban fortification do not only have certain consequences for physical segregation and use patterns, but also embody meaning and often ignites memory. As such Spinks (2001) identifies three similarities between the Apartheid and Post-Apartheid City: use of fear, insider-outsider exclusion and spatial re-settlement. With a sudden post-apartheid potential proximity of difference, citizens have emulated the fear management strategy they previously witnessed that the state operated, that of socio-spatial exclusion and segregation. Therefore, apartheid's strongest legacy is not its physical structure, but rather one of symbolic exclusion (Spinks, 2001, p. 30).

Given this context and historic realities one cannot deny that gated communities can contribute to the establishment of a new apartheid city in South Africa as result of physical segregation and social exclusion (Figure 5). The symbolic and physical meaning of enclosed neighbourhoods may surpass that of any other type of gated community due to its reference to the past and severe impacts on urban functioning. 


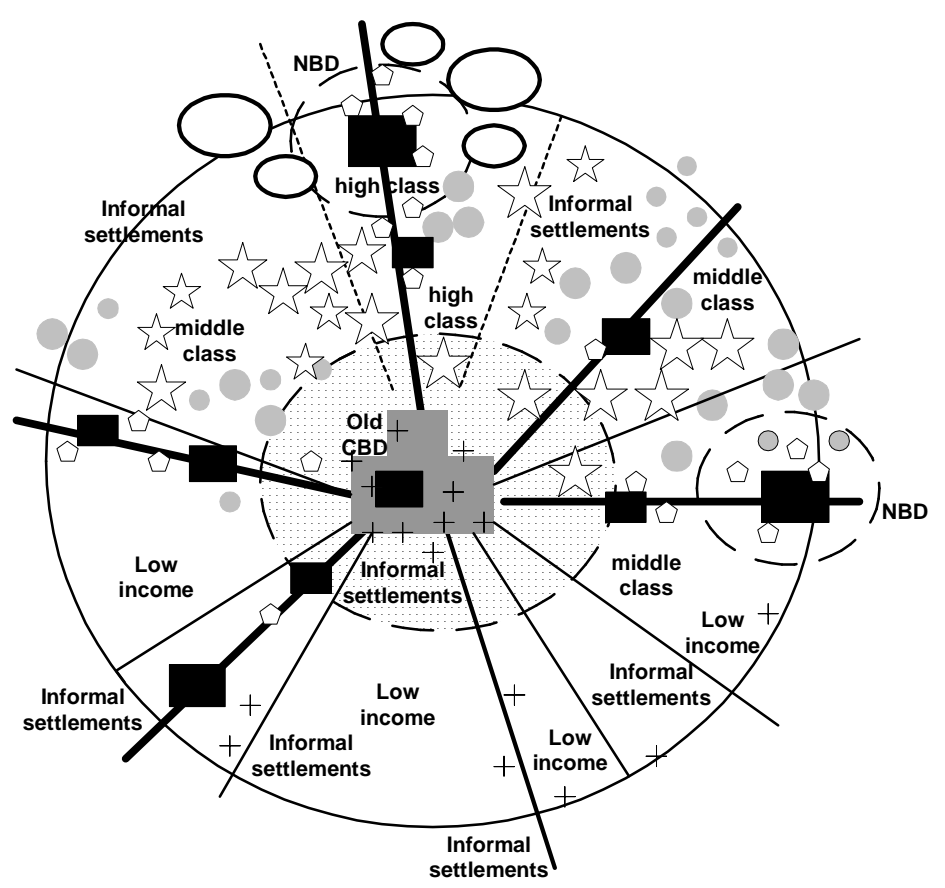

Key:

NBD: New Business Districts

Large nodes (business / industrial)

$\bigcirc$ Older suburbs

$\hat{W}$ Enclosed neighbourhoods

Large security estates

- Secured townhouse complexes

+ Secured high-rise apartments / adapted hostels

$\triangle \quad$ Secure office parks

Figure 5. Gated communities and the new-apartheid city

Meaning is often attached to a particular typology, for example, a military fort, a church, a civic centre, and a prison. While this is true, the form and use of urban space change over time as indicated earlier. As such, the meaning of gated communities may also change, as was illustrated through the example of Tiananmen Square. Thus, while many perceive gated communities (especially enclosed neighbourhoods) as a new form of the old apartheid neighbourhood, and contributing to a new apartheid city due to its nature and extent, this condition may in fact also change over time. This situation does not mean that the current signs of segregation should be ignored.

\section{Conclusion: beyond the barricaded shadowlands}

A radical transformation in South Africa will depend more on how the past is remembered than on how the future is plotted (Depelchin, 1996 cited in Terreblanche, 2002, p. 3).

Gates and fences do matter. They are not mere physical interventions or aesthetic features in the landscape. They represent the control of space by a specific group to the detriment of others. In this sense it may even be more applicable to refer to neighbourhood exclosures than neighbourhood enclosures. They also contribute to the privatisation of public space in South African cities, whether 
formally (through security villages) or more informally (through the establishment of enclosed neighbourhoods).

This paper set out to investigate three broader issues, as they pertain to neighbourhood enclosures: that the built environment embodies meaning, that meaning is influenced by context (socio-spatial), and that both meaning and context are influenced by time (specific period in history). The investigation of enclosed neighbourhoods confirmed these points. I indicated that their establishment embodies both a physical and symbolic meaning: physical as manifested through a limitation to the degree of accessibility to all urban residents, a negation of the concept of equity, and a challenge to greater efficiency in municipalities with large numbers of enclosed neighbourhoods such as Johannesburg and Tshwane. The symbolic meaning was more subtle and related to the interpretation of spatial intervention, thus highlighting the relationship between physical and social space. This point was manifested through examples of seclusion, exclusion and conflict, all caused by increased numbers of enclosed neighbourhoods. These three issues also inevitably offer a link between the past and the future, highlighting the possibility of a new apartheid city in South Africa as a result of a significant growth of many types of gated communities across the urban landscape. While the physical manifestation is rather obvious (the multiplication of numbers causing spatial segregation), it is the symbolic implications (exclusion of certain groups) that especially conjures up the past. As such one cannot consider the meaning of gated communities without understanding the socio-spatial context and time in which they are established (viz., post-apartheid South Africa).

But, it is the establishment of enclosed neighbourhoods that begs greater consideration. Although it may be argued that under apartheid separation was enforced, and that living in a gated community occurs by choice, it does not negate the additional fragmenting impacts that these developments can have in already fragmented and segregated environments. Taking a closer look, some antagonists might interpret this statement slightly differently and argue that many residents are forced to live inside enclosed neighbourhoods or suffer the inconvenience created by them. This observation begs the question if indeed the current situation is very different to the apartheid neighbourhoods. In addition, choice is also most often linked to affordability, which may in fact limit the majority of people in South Africa from living in gated communities, even should they prefer this option to prevent crime.

What do these changes mean for future studies on gated communities? The South African studies present a few lessons. Firstly, it shows that the transformation of the built environment cannot be studied in isolation. The mere fact that physical structure and form embody meaning (both physical and symbolic) emphasise the important relationship between physical and social space. It also underlines the intricate relationship between the meaning of spatial intervention and the specific sociospatial context and time. In this way, while the manifestation of gated communities in different countries may reflect many similarities, their interpretation may vary completely and may also change over time. Secondly, the paper highlighted the concerns regarding enclosed neighbourhoods in South Africa in terms of their impact due to their nature and extent as well as their link to apartheid neighbourhoods of the past. This points out that the impact of different types of gated communities may in fact differ; this point should be considered when discussing the impact of gated communities for cities in the future.

There is no denial that neighbourhood enclosures, or rather exclosures, are contesting public space in South Africa and contributing to the privatisation of public space to a large extent. If one accepts the importance of the public realm in cities, enclosed neighbourhoods pose a significant threat to their continuous existence and more than that, to their celebration for the benefit of all urban residents. As such, it may be argued that enclosed neighbourhoods are creating barricaded shadowlands negating the 
aims of post-apartheid development policies. To move beyond the barricaded shadowlands and achieve a radical transformation in urban South Africa will depend on an acknowledgement of its link to the past, as well as an alternative way to address crime and the fear of others.

\section{Notes}

\section{References}

Banister J. \& Fife N., 2001: Introduction: Fear and the city. Urban Studies 38 (5-6): 807-813.

Bremner L., 1999: Crime and the emerging landscape of post-apartheid Johannesburg. In: Judin H. and Vladislavic I. (eds.), blanc architecture, apartheid and after. Nai Publishers, Rotterdam.

Caldeira T.P.R., 1996: Building up walls: the new pattern of spatial segregation in Sao Paul. In: Unesco Report 147/1996. Published by Blackwell Publishers, Cambridge.

Dewar D., 1992: Urbanization and the South African city: a manifesto for change. In: Smith D.M. (ed.), The Apartheid City and beyond: urbanisation and social change in South Africa. Routledge, London.

Dewar D. \& Uytenbogaardt R., 1991: South African cities: a Manifesto for change. Urban Problems Research Unit and Urban Foundation, Cape Town.

Dewar D., Watson V., Bassios A., \& Dewar D., 1990: The structure and form of metropolitan Cape Town: its origins, influences and performance. Urban Problems Research Unit and Urban Foundation, Cape Town.

Harrison P., 2003: Fragmentation and globalisation as the new meta-narrative. In: Harrison P., Huchzermeyer M. and Mayekiso M. (eds.), Confronting urban fragmentation: housing and urban development in a democratising society. University of Cape Town University Press, Cape Town.

Jürgens, U., Gnad, M. and Bhar, J., 2003: "New forms of Class and Racial Segregation: Ghettos or Ethnic Enclaves" in Tomlinson, R. Beauregard, R.A., Bremner, L. and Mangcu, X. (eds.) Emerging Johannesburg: Perspectives on the Postapartheid City. New York: Routledge, 56-70.

Kostof S., 1992: The City assembled: the elements of urban form through history. Thames \& Hudson, London.

Kotze C.P., 1999: The 'CAPE SCHOOL' towards the understanding and design of the South African city. Open House International 24 (4): 1999: 21-35.

Landman, K. (2003) A National Survey of gated communities in South Africa. CSIR Publication. BOU/I 252.

Lipman A., \& Harris H., 1999: Fortress Johannesburg. Environment and Planning B: Planning and Design 26: 727-740.

Mabin A., 1992: Dispossession, exploitation and struggle: an historical overview of South African urbanization. In: Smith D. (ed.), The Apartheid City and beyond. Urbanization and Social Change in South Africa. Routledge SA, Witwatersrand University Press, London, New York.

Madanipour A., 1996: Design of urban space: and inquiry into a socio-spatial Process. Wigley, London.

Olima W.H.A., 2001: The dynamics and implications of sustaining urban spatial segregation in Kenya - experiences from Nairobi metropolis. International Seminar on Segregation in the City, July 2528,2001, Cambridge, MA.

Pearsall, J. (ed.), 1999: The Concise Oxford Dictionary, $10^{\text {th }}$ edition. Oxford, Oxford University Press. Rapoport A., 1990: The meaning of the built environment. $2^{\text {nd }}$ edition. University of Arizona, Tuscon, AZ.

Robinson J., 1996: The power of apartheid: state, power and space in South African cities. Butterworth-Heinemann, Oxford. 
Ronge B., 2003: Enemy at the gates. Sunday Times Magazine. April.

Short J., 1996: The urban order: an introduction to cities, culture and power. Cambridge: Blackwell Publishers.

Smith D., 2003: Urban fragmentation, inequality and social justice: ethical perspectives. In confronting urban fragmentation: housing and urban development in a democratising society. Cape Town, University of Cape Town University Press.

Spinks C., 2001: A New Apartheid? Urban spatiality, (fear of ) crime and segregation in Cape Town, South Africa. Development Studies Institute, London School of Economics, Working paper series, No. 01-20: 1-42.

Swilling M., Humphries R. \& K. Shubane (eds.), 1991: Apartheid City in transition. Oxford University Press, Cape Town.

Terreblanche S., 2002: A history of inequality in South Africa 1652 - 2002. Natal University Press, Pietermaritzburg.

Tomlinson R., 2003: HIV/Aids and urban disintegration in Johannesburg. In: Confronting urban fragmentation: housing and urban development in a democratising society. University of Cape Town University Press, Cape Town.

Vrodljak M., 2001: Place and the politics of subjectivity. Unpublished thesis. University of the Witwatersrand.

White Paper on Local Government, 1998: Prepared by the Department of Provincial and Local Government, Pretoria.

White Paper on Spatial Planning and Land Use Management, 2001: Prepared by the Department of Land Affairs, Pretoria.

\footnotetext{
${ }^{\mathrm{i}}$ In 2002 CSIR Building and Construction Technology (Boutek) embarked on more extensive research on gated communities in South Africa. This project comprised two phases. The first focused on a national survey (quantitative approach) of gated communities to determine their extent and location. The second comprised four detailed case studies (qualitative approach) to assess the specific reasons for the spatial characteristics, the development and operation and the impact and implications of two types of gated communities (enclosed neighbourhoods and large security estates) in two municipalities (Cities of Johannesburg and Tshwane). The survey was conducted through mail questionnaires sent to all the local and metropolitan municipalities (237) in South Africa. The case study research was conducted through semistructured interviews, a spatial analysis of the four neighbourhoods, and direct observation in the neighbourhoods and documentation review.
}

ii These practices are not limited to South Africa. There are many other examples, especially in old colonial cities, such a São Paulo and Rio de Janeiro in Brazil (Caldeira, 1996) and Nairobi in Kenya (Olima, 2001).

${ }^{\text {iv }}$ As the model of separate spatial development (in terms of separate land use) was based on modern town planning principles, many other cities in the world also have similar spatial characteristics that vary in degree and detail to the South African model.

\footnotetext{
${ }^{v}$ As mentioned earlier, the survey was conducted in 2002. The numbers of gated communities have increased in some areas since then, notably Johannesburg and Tshwane.

${ }^{v i}$ The provincial Government of Gauteng incorporated a chapter (Chapter 7) in the Rationalisation of Local Government Affairs Act, No. 10 of 1998, to deal with access restrictions for security purposes. Chapter 7 makes provision for a local authority to restrict access into an area for purposes of enhancing safety and security. The local authority may restrict access on its own initiative, or may authorise any legal body or institution to do so, as in the case of neighbourhood closures. They may, however, not prohibit access into these areas.
} 